\title{
Children as carers: an integrative review
}

\author{
Ana Sofia Filipe Marote ${ }^{1}$ \\ Carla Andreia Pinto ${ }^{2}$ \\ Marlene da Rocha Vieira ${ }^{3}$ \\ Maria do Céu Aguiar Barbiéri-Figueiredo ${ }^{4}$ \\ Pedro Miguel Nunes Pedrosa ${ }^{5}$
}

Objective: to undertake an integrative literature review on the issue of "Children as carers". This is an emerging topic in the provision of health care, but nevertheless has a low profile in the literature. Methodology: this study was based in a survey of nine databases of scientific articles, using as descriptor: child, young, caregivers, lay carer and nursing role, as well as the corresponding terms in Portuguese. 21 articles were analyzed. Results: these were organized into six categories - factors which motivate the child to take on the role of caregiver; these children's characteristics; tasks performed; time spent in caring; consequences of providing care and the role of the nurse in partnership with these children and their families. Conclusion: the children as carers are a focus of attention relevant to nursing practice, this issue representing an opportunity for investigation in Portuguese-speaking countries, as no article was found on the subject in Portuguese. In addition, with this first study in Portuguese, a work of the creation of a bibliography is begun, allowing an awareness of the issue and the identification of ways to respond to the families involved, in line with their needs.

Descriptors: Child; Adolescent; Caregivers; Nursing Care.

\footnotetext{
${ }^{1} \mathrm{RN}$, Four Seasons Health Care, Derry, Ireland.

2 RN, Hospital Gérontologique et Medico Social de Plaisir Grignon, France.

${ }^{3}$ RN, Securilabor - Centro de Segurança Medico Laboral, Portugal.

${ }^{4} \mathrm{PhD}$, Professor, Escola Superior de Enfermagem do Porto, Portugal.

${ }^{5}$ RN, Hospital da Santa Maria, Portugal.
} 


\section{Crianças como cuidadoras: revisão integrativa}

Objetivo: realizar uma revisão bibliográfica integrativa do tema "Crianças como Cuidadoras". Trata-se de tema emergente na prestação de cuidados de saúde que, contudo, se mantém pouco visível na literatura. Metodologia: baseou-se numa pesquisa sobre nove bases de dados de artigos científicos, utilizando-se como descritores: child, young, caregivers, lay carer and nursing role, bem como os correspondentes em português. Foram analisados 21 artigos. Resultados: foram organizados em seis categorias: fatores que motivam a criança a assumir o papel de cuidadora; caraterísticas dessas crianças; tarefas desempenhadas; tempo passado a cuidar; consequências da prestação de cuidados e papel do enfermeiro em relação a essas crianças e suas famílias. Conclusão: as crianças como cuidadoras são um foco de atenção relevante para a prática de enfermagem, representando esse tema uma oportunidade de investigação nos países de língua portuguesa, já que não foi encontrado qualquer artigo em português sobre o mesmo. Além disso, com este primeiro estudo em língua portuguesa, inicia-se um trabalho de criação bibliográfica que permita a sensibilização para o tema e a identificação das respostas a dar às famílias envolvidas, de acordo com as suas necessidades.

Descritores: Crianças; Adolescentes; Cuidadores; Cuidados de Enfermagem.

\section{Niños como cuidadores: revisión integrativa}

Objetivo: realizar una revisión bibliográfica integrativa del tema "Niños como Cuidadores". Se Trata de un tema emergente en la prestación de atenciones de salud, que sin embargo se mantiene poco visible en la literatura. Metodología: se basó en una investigación sobre nueve bases de datos de artículos científicos, utilizándose como descriptores: child, young, caregivers, lay carer y nursing role, así como los correspondientes en portugués. Fueron analizados 21 artículos. Resultados: fueron organizados en seis categorías - factores que motivan el niño a asumir el papel de cuidador; características de esos niños; tareas desempeñadas; tiempo pasado a cuidar; consecuencias de la prestación de atenciones y papel del enfermero junto de esos niños y sus familias. Conclusión: los niños como cuidadores son un foco de atención relevante para la práctica de enfermería, representando ese tema una oportunidad de averiguación en los países de idioma portugués, ya que no fue encontrado cualquier artículo en portugués sobre el mismo. Además, con éste primer estudio en idioma portugués, se inicia un trabajo de creación bibliográfica que permita la sensibilización para el tema y la identificación de las respuestas a dar a las familias envueltas, de acuerdo con sus necesidades.

Descriptores: Niños; Adolescentes; Cuidadores; Atención de Enfermería.

\section{Introduction}

The concept of young carers is recent and may be defined as children and adolescents up to 18 who provide care in a significant and regular way, in activities of daily living, for family members or others who live in the same house and who need help due to chronic or prolonged physical or mental illness, age-associated dependence, or other conditions. These children take on a determined responsibility which - at least in Western societies - is not normally intended for them ${ }^{(1-4)}$. This type of care may include one or more of the following components: personal care, health care, house-keeping, supervision, specific behaviors referent to discharge from the hospital setting, and emotional support. The children may provide care directly or indirectly, and the fact on its own of taking on the responsibility for an adult's health encompasses the ambit of caring ${ }^{(3-5)}$. It is important to note that taking on this role is closely related to the population's demographic and sociocultural context ${ }^{(5-6)}$.

Traditionally, children and young people are brought up to participate in domestic tasks(1). Fifteen years ago, the United Kingdom pioneered the legal recognition of the existence of young carers. Currently, Australia and the United States of America (USA) are following in the UK's footsteps $^{(2)}$.

Knowledge about young carers is extremely limited. In the United Kingdom, in 2001, 175,000 young 
carers were identified, representing $2.1 \%$ of all children there ${ }^{(2,7)}$. In Australia, in 2003, 169,900 young carers were identified, $3.6 \%$ of the total of children, and - for 2005 - it was estimated that in the USA there were 1.3 to 1.4 million young carers, from 8 to 18 years of age, forming $3.2 \%$ of the population ${ }^{(6)}$.

The present research aimed to undertake an integrative review of studies relating to children as carers, and to identify the role performed by nurses along with these children.

The integrative literature review is seen as a research method which allows the incorporation of evidence from clinical practice, aiming to bring together and summarize the results of multiple research projects on a specified topic in a systematic and ordered way, contributing to the deepening of knowledge on the issue investigated. Therefore, in constructing this integrative review, certain stages were followed, such as the constitution of objectives, determination of inclusion and exclusion criteria for articles, clarification of the information to be highlighted from the selected and analyzed articles, analysis of the results, presentation and discussion of the results, and - finally - presentation of the conclusions obtained in the review ${ }^{(8)}$.

\section{Formulation of the question}

This review aimed to respond to the following questions: How are young carers characterized, and what is the role of the nurse in the face of the needs shown by these children in providing nursing care.

\section{Method}

\section{Method of finding and selecting the studies}

Literature reviews were carried out at two points during the process of collection of information: the first between February and May 2010, and the second between October and December of the same year. In the latter, the authors resorted to a further survey for improving the updating of the information already gathered.

The electronic survey was undertaken in the following databases: the b-on portal; on MEDLINE (EBSCO); CINAHL (EBSCO); Medic Latina (EBSCO); Psychology \& Behavioral Sciences Collection (EBSCO); Academic Search (EBSCO); Cochrane database of systematic reviews (EBSCO); SciELO and ADOLEC. This survey included different types of scientific articles, with preference being given to articles published in the previous ten-year period. However, the authors could not leave out some articles found with more than 10 years since publication, as these had been the basis of more recent articles found, which had information relevant to the subject being studied.

The literature survey on this topic in Portuguese gave no results at all. As a result, the survey was carried out with the descriptors in English, Child; young; caregivers; lay carer and nursing role, as may be seen in Figure 1, with all articles which contained these key words in one or more of their fields being considered.

\begin{tabular}{|c|c|c|c|}
\hline Boolean combination & All the fields & Field topic & Field title \\
\hline Child or young and caregivers or lay carer and nursing role & $\begin{array}{l}\text { EBSCO: } 14 \\
\text { B-On: } 144 \\
\text { Scielo: } 0 \\
\text { ADOLEC: } 0\end{array}$ & $\begin{array}{l}\text { EBSCO: } 0 \\
\text { B-On:38 } \\
\text { Scielo: } 0 \\
\text { ADOLEC: } 0\end{array}$ & $\begin{array}{l}\text { EBSCO: } 0 \\
\text { B-On:30 } \\
\text { Scielo:0 } \\
\text { ADOLEC: } 0\end{array}$ \\
\hline Child or young and caregivers or lay carer and nursing & $\begin{array}{c}\text { EBSCO: } 662 \\
\text { B-On:189 } \\
\text { Scielo: } 0 \\
\text { ADOLEC: } 70\end{array}$ & $\begin{array}{c}\text { EBSCO:0 } \\
\text { B-On:61 } \\
\text { Scielo:0 } \\
\text { ADOLEC: } 0\end{array}$ & $\begin{array}{l}\text { EBSCO:1 } \\
\text { B-On:31 } \\
\text { Scielo:0 } \\
\text { ADOLEC:0 }\end{array}$ \\
\hline Child or young and caregivers or lay carer & $\begin{array}{c}\text { EBSCO: } 4978 \\
\text { B-On: } 147 \\
\text { Scielo: } 10 \\
\text { ADOLEC: } 523\end{array}$ & $\begin{array}{l}\text { EBSCO:0 } \\
\text { B-On:90 } \\
\text { Scielo:9 } \\
\text { ADOLEC: } 0\end{array}$ & $\begin{array}{l}\text { EBSCO:56 } \\
\text { B-On:61 } \\
\text { Scielo:0 } \\
\text { ADOLEC: } 5\end{array}$ \\
\hline
\end{tabular}

Figure 1 - Survey descriptors and number of articles obtained

To avoid silent areas, the authors resorted to an inverse survey. This is a method for selecting documents based on the bibliography of the primary studies, where articles were sought which these same studies had used, aiming for a survey of literature which is not available in the scientific databases( ${ }^{(8)}$.

In selecting publications, the studies were included which - from the analysis of the abstracts - corresponded to the following inclusion criteria: to study children aged up to 18 who provided or provide care, to study adults who were young carers, and to study the link between provision of care by children and health. However, some studies were found which - while meeting all the inclusion criteria - identified 19 years as the age limit for young carers. These articles were analyzed, with only the results and conclusions from studies of children up 
to 18 years of age being used.

Whenever a study's title or abstract was unclear, the article was read in full, so as to avoid the risk of leaving an important study out of the review.

After the selection of the studies to be analyzed, and having adopted the inclusion criteria, the authors progressed to the phase of the process of the review, in which a total of 21 documents localized were submitted to critical evaluation.

\section{Procedures for data collection and the critical evaluation of the studies}

The analysis of the primary studies' quality considered the date and the structure of publication, regarding the study objectives, the methodology, the results and the conclusions obtained in each one. To this end a spreadsheet was created, using Microsoft Excel 2007, with the extraction of information and its inputting on the spreadsheet being undertaken by two independent evaluators.

The decision as to the selected documents' relevance for analysis also depended on the scientific clarity and consistency with which the data referent to the methodology, participants and results were described in the content of each text.

\section{Results}

Figure 2 allows a comparative reading of the information collected from each of the sources considered relevant and included in the study, presented in chronological order.

\begin{tabular}{|c|c|c|c|}
\hline $\begin{array}{l}\text { Author(s), year and } \\
\text { country of publication }\end{array}$ & Type of study & Population studied & Aspects addressed \\
\hline $\begin{array}{l}\text { Aldridge \& Becker (1993) } \\
\text { United Kingdom }^{(9)}\end{array}$ & Qualitative study & $\begin{array}{l}15 \text { young carers in Nottinghamshire and } \\
\text { the multidisciplinary support team (health; } \\
\text { social and voluntary). }\end{array}$ & $\begin{array}{l}\text { Characterization of the children; Formal and } \\
\text { informal support for these carers; Effects of } \\
\text { care provision; Needs expressed; Relationship } \\
\text { with health care professionals. }\end{array}$ \\
\hline $\begin{array}{l}\text { Aldridge \& Becker (1994) } \\
\text { United Kingdom }^{(10)}\end{array}$ & Qualitative study & 10 parents of young carers. & $\begin{array}{l}\text { Formal and informal support networks; } \\
\text { Effects on the children of providing care; } \\
\text { The care relationships; The parents' and } \\
\text { children's needs; The children's rights and } \\
\text { responsibilities. }\end{array}$ \\
\hline $\begin{array}{l}\text { Becker (1995) United } \\
\text { Kingdom }^{(11)}\end{array}$ & $\begin{array}{l}\text { Compilation of articles } \\
\text { from a literature } \\
\text { review }\end{array}$ & $\begin{array}{l}5 \text { articles on this issue, produced in } \\
\text { different European countries. }\end{array}$ & $\begin{array}{l}\text { Characterization of the children; perspective of } \\
\text { the young carers; The effects of the care; The } \\
\text { parents' perspective: the legislative forces; The } \\
\text { children's rights; Responses to the children's } \\
\text { needs; The professionals' responsibilities; } \\
\text { professional support and social services. }\end{array}$ \\
\hline $\begin{array}{l}\text { Gays }(2000) \\
\text { Australia(3) }^{(3)}\end{array}$ & Quantitative study & $\begin{array}{l}\text { Undefined number of young carers from } \\
\text { Australian secondary schools and colleges. }\end{array}$ & $\begin{array}{l}\text { Characterization of the children; Who cares; } \\
\text { Which pathologies people receive care for; } \\
\text { What care is provided; What tasks they wanted } \\
\text { to see developed/supported. }\end{array}$ \\
\hline $\begin{array}{l}\text { Lackey \& Gates (2001) } \\
\text { USA }^{(12)}\end{array}$ & $\begin{array}{l}\text { Retrospective } \\
\text { quantitative study }\end{array}$ & $\begin{array}{l}51 \text { adults aged between } 19 \text { and } 68 \text { who } \\
\text { were carers (between } 3-18 \text { years) of family } \\
\text { members with chronic illnesses. }\end{array}$ & $\begin{array}{l}\text { Care activities; Advantages and disadvantages } \\
\text { in caring; Tasks which they liked and disliked; } \\
\text { Effect of care on school, friends and leisure; } \\
\text { Role of the nurse. }\end{array}$ \\
\hline $\begin{array}{l}\text { Frank }(2002) \\
\text { London }^{(13)}\end{array}$ & $\begin{array}{l}\text { Compilation of articles } \\
\text { from a review of the } \\
\text { literature }\end{array}$ & $\begin{array}{l}7 \text { articles from a literature review, each } \\
\text { dedicated to an issue related to young } \\
\text { carers }\end{array}$ & $\begin{array}{l}\text { Contextualization; Children's needs and } \\
\text { questions; Young carers' exchange of } \\
\text { experiences; Evaluation of care provision by } \\
\text { children; effective support services. }\end{array}$ \\
\hline $\begin{array}{l}\text { Banks, Gallagher, Hill \& } \\
\text { Riddell. (2002) } \\
\text { United Kingdom }^{(14)}\end{array}$ & Literature review & $\begin{array}{l}\text { Undefined number of articles by } \\
\text { institutions of support for young carers, } \\
\text { of questionnaires administered in local } \\
\text { institutions of health and safety, and } \\
\text { volunteer institutions for support to these } \\
\text { children in the UK. }\end{array}$ & $\begin{array}{l}\text { Role of authorities (social workers, teachers, } \\
\text { nurses); Definition and characterization of } \\
\text { young carers; What their needs are; Support } \\
\text { services. }\end{array}$ \\
\hline $\begin{array}{l}\text { Thomas, Stainton, } \\
\text { Jackson, Cheung, } \\
\text { Doubtfire \& Webb (2003) } \\
\text { United Kingdom(15) }\end{array}$ & Qualitative study & $\begin{array}{l}27 \text { young carers aged between } 9 \text { and } 18 \\
\text { years old caring for parents who were ill, } \\
\text { alcoholics or with mental disabilities, or } \\
\text { for siblings with disabilities or behavioral } \\
\text { problems. }\end{array}$ & $\begin{array}{l}\text { Characterization of the children and their } \\
\text { needs; Inversion of family roles; Their } \\
\text { experiences and perspectives for the future; } \\
\text { The lack of support and awareness on the part } \\
\text { of education, social and health professionals; } \\
\text { Importance of investigation of the matter. }\end{array}$ \\
\hline $\begin{array}{l}\text { Dearden \& Becker (2004) } \\
\text { United Kingdom }{ }^{(16)}\end{array}$ & Literature review & $\begin{array}{l}2 \text { reports of the activities of } 82 \text { projects } \\
\text { undertaken with young carers between } \\
1995 \text { and } 1997 \text { in the UK. }\end{array}$ & $\begin{array}{l}\text { Characterization of the young carer and the } \\
\text { recipient of the care: statistical data; Types of } \\
\text { care they provide; Health problems of those } \\
\text { needing care; Time spent in providing care; } \\
\text { Impacts on education; Evaluation of young } \\
\text { carers. }\end{array}$ \\
\hline
\end{tabular}




\begin{tabular}{|c|c|c|c|}
\hline $\begin{array}{l}\text { Author(s), year and } \\
\text { country of publication }\end{array}$ & Type of study & Population studied & Aspects addressed \\
\hline $\begin{array}{l}\text { Robson; Ansell; Huber; } \\
\text { Gould \& Young (2006) } \\
\text { United Kingdom }\end{array}$ & Systematic review & $\begin{array}{l}\text { Meta-synthesis of } 3 \text { studies with qualitative } \\
\text { and quantitative elements, with children } \\
\text { who care for family members with HIV in } \\
\text { sub-Saharan Africa. }\end{array}$ & $\begin{array}{l}\text { Tasks which young carers carry out; Positive } \\
\text { and negative impacts of caring for adults. }\end{array}$ \\
\hline $\begin{array}{l}\text { Siskowski (2006) } \\
\text { USA }^{(4)}\end{array}$ & $\begin{array}{l}\text { Descriptive } \\
\text { quantitative study }\end{array}$ & $\begin{array}{l}12681 \text { students from public schools, aged } \\
\text { between } 6 \text { and 12, in Palm Beach county. }\end{array}$ & $\begin{array}{l}\text { Influence of providing care on school } \\
\text { performance; Role of nursing in this area. }\end{array}$ \\
\hline $\begin{array}{l}\text { Earley, Cushway, \& } \\
\text { Cassidy (2007) } \\
\text { Ireland (17) }\end{array}$ & Qualitative study & $\begin{array}{l}\text { Undefined number of children between } \\
10 \text { and } 16 \text { who care for family members } \\
\text { with AIDS, mental illness of problems with } \\
\text { alcohol or drugs. }\end{array}$ & Impact of providing care on the young person. \\
\hline $\begin{array}{l}\text { Evans \& Becker (2007) } \\
\text { United Kingdom }{ }^{(18)}\end{array}$ & Qualitative study & $\begin{array}{l}\text { Undefined number of young carers of } \\
\text { adults in the UK and Tanzania who care for } \\
\text { family members with HIV and their family } \\
\text { members. }\end{array}$ & $\begin{array}{l}\text { Characterization of the children and the care } \\
\text { given; Impact of HIV/AIDS on the families } \\
\text { and children; Consequences for emotional } \\
\text { well-being, physical health and personal } \\
\text { development of the child as a result of providing } \\
\text { care; Impact on family relationships, education } \\
\text { and the community; Formal and informal } \\
\text { support; Need for recognition of the children's } \\
\text { responsibilities and adjustment of the extant } \\
\text { policies. }\end{array}$ \\
\hline $\begin{array}{l}\text { Metzing, Schnepp, } \\
\text { Hubner \& Bucher (2007) } \\
\text { Germany }{ }^{(19)}\end{array}$ & Qualitative study & $\begin{array}{l}34 \text { families with a member with a chronic } \\
\text { illness (physical or psychological) in } \\
\text { Germany, focusing on } 41 \text { children aged } \\
\text { between } 4.5 \text { and } 19 \text { years old. }\end{array}$ & $\begin{array}{l}\text { Characterization of the children; Distribution of } \\
\text { tasks in the family; Type of tasks carried out; } \\
\text { Who provides the care; internal factors which } \\
\text { interfere in care provision or obtaining the } \\
\text { same; Informal and formal support. }\end{array}$ \\
\hline $\begin{array}{l}\text { Warren, (2007) } \\
\text { United Kingdom }\end{array}$ & Qualitative study & $\begin{array}{l}390 \text { children and youngsters aged between } \\
9 \text { and } 18 \text { years old }\end{array}$ & Tasks undertaken; Role of the nurse. \\
\hline $\begin{array}{l}\text { Becker (2007) } \\
\text { United Kingdom }{ }^{(6)}\end{array}$ & Literature review & $\begin{array}{l}\text { Undefined number of articles about young } \\
\text { carers, published in the UK, Australia, USA } \\
\text { and Sub-Saharan Africa. }\end{array}$ & $\begin{array}{l}\text { Definition of young carers; Analysis of this } \\
\text { context: Characterization of the children; } \\
\text { what care they give; positive and negative } \\
\text { consequences; Factors which motivate to take } \\
\text { on this role; Comparison of this context with } \\
\text { different countries; Message for health care } \\
\text { professionals. }\end{array}$ \\
\hline $\begin{array}{l}\text { Aldridge (2008) } \\
\text { United Kingdom }\end{array}$ & Literature review & $\begin{array}{l}\text { Undefined number of articles about children } \\
\text { caring for parents with serious mental } \\
\text { illness. }\end{array}$ & $\begin{array}{l}\text { The contradictions of care provision; The child's } \\
\text { understanding of mental illness; Children's } \\
\text { occupation with care rather than toys; } \\
\text { Importance of the life of the child as a child. }\end{array}$ \\
\hline $\begin{array}{l}\text { Becker; Becker (2008) } \\
\text { United Kingdom }\end{array}$ & $\begin{array}{l}\text { Compilation of articles } \\
\text { from a literature } \\
\text { review }\end{array}$ & $\begin{array}{l}19 \text { articles, of which only } 12 \text { were analyzed, } \\
\text { as the rest had to do with young carers } \\
\text { aged over } 18 .\end{array}$ & $\begin{array}{l}\text { Legislation; Statistic data; Factors which } \\
\text { motivate the child to take on the role of carer; } \\
\text { Responsibility and tasks in caring; Negative } \\
\text { and positive consequences of caring; Young } \\
\text { carers' needs; A recommended norm for } \\
\text { identifying young carers. }\end{array}$ \\
\hline $\begin{array}{l}\text { Gray; Robinson; Seddon } \\
\text { (2008) } \\
\text { United Kingdom }\end{array}$ & Qualitative study & $\begin{array}{l}\text { Undefined number of professionals from } \\
\text { the health sector and social services. }\end{array}$ & $\begin{array}{l}\text { The professionals' vision of the needs of } \\
\text { children who care for adults with psychiatric } \\
\text { problems; Perception of the young carers on } \\
\text { isolation; restricted opportunities and stigma; } \\
\text { Fears related to the protection of minors and } \\
\text { separation of families; Examples of good } \\
\text { practice by professionals which should be } \\
\text { fostered. }\end{array}$ \\
\hline $\begin{array}{l}\text { Metzing \& Schnepp } \\
\text { (2008) Germany (22) }\end{array}$ & Qualitative study & $\begin{array}{l}41 \text { young carers and } 41 \text { parents of these } \\
\text { children. }\end{array}$ & $\begin{array}{l}\text { Characterization of the children; The } \\
\text { expectations experienced by the children and } \\
\text { their needs; Construction of a model of the } \\
\text { experiences and reconstruction of the family for } \\
\text { the undertaking of care. }\end{array}$ \\
\hline $\begin{array}{l}\text { Obadina }(2010) \\
\text { United Kingdom } \\
\end{array}$ & Literature review & $\begin{array}{l}\text { Undefined number of articles about } \\
\text { children who provide care to adults with } \\
\text { mental illness in the UK. Number of articles } \\
\text { analyzed not defined by the author. }\end{array}$ & $\begin{array}{l}\text { Characterization of the children: statistical data; } \\
\text { Impact of the care on the children; Role of the } \\
\text { nurses. }\end{array}$ \\
\hline
\end{tabular}

Figure 2 - Selected studies on young carers and their impact on the provision of health care 
As a way of organizing the vast content presented in the articles included in this study, the authors decided to organize it through critical and qualitative analysis systematizing it in the following topics which emerged from its integrated reading and which are presented below.

\section{Topic 1 - Factors which motivate the child to take on the role of carer}

The quantity of children who take on the role of carer is to increase. In Western countries, factors such as the high prevalence of single-parent families, the increase in average life expectancy and the tendency of adults to acquire chronic illnesses earlier lead the investigators to conclude that often the child takes on the role of carer because of being the only family member available ${ }^{(4)}$, considering that many families still show difficulty in accepting people from outside the family context to provide care ${ }^{(10)}$.

The situation of children providing care, due to its complexity, can only be understood if one takes into account the following facts: scarce material and financial resources, the nature and extent of the illness/ disability, the concept of family and family values, the expectations/beliefs, the structure and dynamics of the family relationships, the absence of another person to take on the role of carer, the carer's ethnic and cultura affiliation and their age and gender, which inevitably will influence the provision of care ${ }^{(1-2,6,19)}$.

In addition to what has been mentioned, other factors increase the likelihood of the children providing care, including: separated families, precarious living conditions, adolescent mothers and extended families. All these factors suggest that living together or proximity is a common factor for all the children who provide care ${ }^{(16)}$. The evidence is scarce as to which factor predominates in taking on this role, although various studies point to poverty and low economic income as being highly relevant ${ }^{(2,16)}$

\section{Topic 2 - These children's characteristics}

The literature reviewed evidences that the young carers have an average age of 12 years, and that the majority are female(5)

The children's acquisition of the role of carer, in contrast with adult carers, is less related to traditional patterns, being linked to a question of necessity of providing the care due to the lack of another family member who can provide $i^{(2)}$. About $12 \%$ of young carers provide care to more than one person and $21 \%$ receive no social support or support from the health system $^{(6)}$.

The young carers are difficult to identify due to their silence. This silence often results from fear and stigma; fear that, for example, making contact with health professionals could result in them being separated from their families. The lack of support and help given to young carers by family, friends and neighbors is surprising ${ }^{(9,15-16)}$.

Moreover, it is emphasized, that the results obtained indicate four large areas in which the children demonstrate needs: information (their parents' health conditions and services); individual support and counseling; practical assistance (teaching and training about tasks to be done by the children); social contact and recreation ${ }^{(2,12,14)}$.

It seems evident that young carers around the world may have more in common than what separates them geographically, economically, politically, socially and culturally. Nationality aside, their tasks and responsibilities are very similar ${ }^{(6)}$

\section{Topic 3 - Tasks performed}

One of the principal aspects of the literature found focuses on the activities which a young carer performs. This aspect is crucial for the health and social work professionals, bearing in mind that only by knowing these children's reality can they help them to perform this role ${ }^{(2,9)}$. In general, many of these young carers have the same type of tasks and responsibilities as adult carers ${ }^{(6)}$. This care may be grouped into six subcategories: support in the activities of daily living, emotional support, help in health care and administration of therapy, help in translation, and help in observation and protection, as well as help in the event of emergency $(9,18)$.

In the dimension - Support in activities of daily living - the young carer carries out tasks in areas such as: Feeding: making food/drink available; cutting up food; preparing meals; Self-care Hygiene: giving baths; helping with partial personal hygiene; placing the wheelchair in the empty shower/bath; providing bathing materials; Dressing/Undressing: shoes, socks, clothes; doing up and undoing buttons and belts on visiting the bathroom; Mobility and Movement: getting up/sitting; Transferring; going up stairs; helping in walking; removing trip hazards; pushing the wheelchair; lying somebody in bed; and - finally - Excretion: accompanying to the bathroom; helping the mother/ 
father to support themselves on the toilet; emptying the catheter bag; changing the continence pads $(2,7,10,12,18-19)$.

Of all the tasks the children face, personal hygiene care was referred to as the most difficult to deal with ${ }^{(10,12)}$, being a type of care which a fifth $(20 \%)$ of children undertake ${ }^{(2)}$.

In the emotional element, the care can range from affectionate contact, which includes actions of stroking, entertaining and consoling, being present at sad moments and holding one's hand(19). Around $80 \%$ of children participate in this type of care ${ }^{(2)}$.

In addition to the tasks mentioned above which the children carry out, it can be verified that, irrespective of age, they participate in the management of health care, such as managing or administering medications or treating wounds, and also ensure the safety of the dependents ${ }^{(19)}$. Around $50 \%$ of the young carers have tasks which involve general nursing care and administration of medication ${ }^{(2)}$.

The care which the children provide to the dependent person includes instruction, guidance and observation about correct and incorrect behaviors and language training; entertainment and leisure activities are also provided ${ }^{(1-2,5,19)}$.

There is no evidence about distinctions in these tasks for children from rural or urban environments(3).

\section{Topic 4 - Time spent caring}

Many of the young carers start caring activities very early in their lives and may continue in the role of carer for several years, often extending out of childhood. Approximately one in every ten young carers spends more than 50 hours a week providing care ${ }^{(1-2,6)}$.

Of the young carers, $83 \%$ spend up to 19 hours per week caring for a family member, $9 \%$ between 20 and 49 hours and $8 \%$ more than 50 hours per week ${ }^{(1-2,6)}$.

The prevalence of the care, in $80 \%$ of the cases, lasts up to five years, $17 \%$ between 6 and 10 years, and $3 \%$ over ten years. Bearing in mind that the young carers' average age is 12 , the data from recent studies indicates that the care can be a long-lasting activity, that this compromise can start at an early age, and that it can continue through to adulthood(1-2,6).

\section{Topic 5 - Consequences of providing care}

The parents trust their children's skill and ability to provide care. Even though care provision may have started at an early age, the parents assure that the children's provision is good, despite there being potentially embarrassing tasks, such as hygiene care.
The parents who are dependent on the children to provide their care, in spite of being aware that these should not be taking on this role, consider it important; this is because they rely on them, not only because of the fact that they are so close to them, but also because they keep them company ${ }^{(7,10)}$.

These children's parents seem either to be uninformed about the problems related to care provision by the children, or may not want to admit that there may be problems ${ }^{(10,15)}$.

The authors of the studies analyzed present the following advantages for the fact of the children being carers:

- It develops in the children intelligence, perception, a feeling of responsibility, maturity, and personal and social skills ${ }^{(1,5-6,12,15,17)}$;

- It brings the family together and reinforces the family's emotional ties $(1,5-6,12,15,17)$;

- It relieves the child's fears and anxiety about the state of the family member's condition(1,5-6,14-16);

- It increases the ability to manage the care ${ }^{(1,5-6,12,17)}$;

- It increases the children's feeling of belonging(1,5-6,13,17).

In spite of all the gratification which may be experienced through the simple act of caring, there are indications that being a carer may have a significant negative impact on the child's activities and his or her environment, such as:

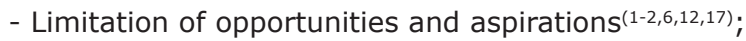

- Limitation of opportunities for leisure and social contact $^{(1-2,6-7,12,15,17)}$;

- Lack of understanding of peers, and few friendships ${ }^{(1-2,6,12,15,17)}$;

- Stigma(1-2,6-7,12,17);

- Feeling of exclusion and isolation $(1-2,4-6,12,15,20)$;

- Fear of separation from his or her family ${ }^{(1-2,6,12,15,17) ;}$

- Experience of providing care in silence and in secret $^{(1-2,6,12,15,17)}$;

- Difficulties in expressing emotion ${ }^{(1-2,6,12,17)}$;

- Difficulties in learning/school progress ${ }^{(1-2,4-7,12,17,20)}$;

- Health problems: stress, burnout, tiredness ${ }^{(1-2,6,12,17)}$;

- Difficulty in making the transition to adulthood(1-2,6,11,17);

- Difficulty in finding a job ${ }^{(1-2,6,12,17)}$;

- Lack of recognition and support(1-2,6-8,12,15,17).

\section{Topic 6 - Role of the nurse in partnership with these children and their families}

Although health professionals' knowledge about young carers has increased, it remains without visibility, as these children's needs continue not to be identified or $\operatorname{met}^{(7,14-15)}$. 
It has been ascertained that only a small proportion of young carers request monitoring in the health institutions, but in practice, the few evaluations which are made, when the child requests this support, tend to be superficial and unfocused. The health professionals too have not exercised active participation together with young carers. This negligence may be linked to limitations of time, resources, and to lack of knowledge about this reality, as well the children are underestimated as to underestimation or contempt of their role as carers $(3,7,11,15)$.

In general, many of the young carers have the same type of tasks and responsibilities as adult carers, such as consequences for relationships, health, well-being and education. In the face of this, a preventive intervention is equally necessary, as, if the young carers and their families take the decision that the provision of care by the child is the only viable solution, support services and benefits capable of avoiding negative consequences and improving care quality, as well as the health of both the patient and carer, must be made available. (6-7).

Of all the studies analyzed, only five were authored by nurses and dealt with the possibilities for this professional's intervention with the young carers. The first stage of intervention by the nurse in this context could be the needs evaluation ${ }^{(15,19)}$. The nurse must determine the resources and support systems for the dependent person and family, including more distant relatives, neighbors and friends. The nurse would also have to assess the ill person's attitude to the care given, such as the reactions of the family member in the face of the recently-acquired role of caregiver. In addition, the nurse must try to find out if the dependent person and their family possess adequate coping mechanisms, to confront the disease, and whether there is some stressing factor in the home. This planning process must also cover evaluation of the family in terms of teaching, counseling and nursing care. The appropriate approach should include the whole family and each individual in it(2).

The interventions undertaken along with the carers should be conducted in line with the three principal elements: psychological support, education with practical training and information and social systems for support $(2,7,12,14)$.

\section{Discussion}

The present review has a predominance of articles by authors from the United Kingdom, comprising a total of 16 studies, one of which was about the African context. However, a further two studies carried out in the USA were identified, along with two undertaken in Australia and three in Germany. The compilation of information relative to the characterization of young carers, perception of types of care given and to whom, the needs which these children feel in providing care, the consequences arising from this care and the role of the nurse resulted from the analysis of these studies. Adding to all this, the studies undertaken in the USA clearly describe the advantages and disadvantages of caring, studying which tasks the children like and do not like carrying out. From Australia, the contributions added the study of the pathologies of the persons being cared for, and finally, the studies undertaken in Germany try to perceive which factors lead the children not to ask for help from outside, instead taking on this responsibility.

Based on the studies analyzed, the authors ascertained that in the majority of countries where these were undertaken, it is foreseen that the number of people who will need health care, namely provision of care in the home, will be greater than the active population, due to low birthrates and the increase in the aging of the population. To this one can add the fact that there is a constant increase in single-parent families and nuclear families in which the illness of one member results in the other taking over the role of supporting the family. If to this fact one adds the ever-earlier development of chronic illnesses - that is, between 40 and 50 years old - a large proportion of these people's children have the likelihood of experiencing the role of young carer $^{(2,19)}$. Contrary to the demographic data of the majority of countries studied, one can verify that in Africa there is an increase in birthrates allied with an increase in chronic illnesses, principally HIV, which has as its consequence the early death and invalidity of these countries' population, leading to an increase in the adults' vulnerability and the necessity for children to care for them(5).

In all these situations the children take on the role of carers, however, taking into account the current literature, the authors can verify that the way that family roles are restructured has been neglected - this is the reason the issue should be increasingly investigated in nursing $(5,10)$.

Given the characterization of the young carers, these face great psychological pressure through the act of taking on - often "forced" - the role of carer. Thus, it is essential that health care professionals should be alert, as these children are more vulnerable and may 
come to adopt the same behaviors of risk as their family members ${ }^{(10)}$.

Bearing in mind that the acquisition of the role of carer leads to the addition of one more role to the individual's normative roles when the behavioral expectations alter significantly, this entails that the carer has to re-organize his or her daily routine(21). This reorganization may be confused with the inversion of roles, where the children are seen, sometimes, as parents by their parents(18). The term "young carers" itself is often seen as a warning for the ill parents, as it puts them in a position of dependency or incapacity ${ }^{(7,15)}$.

The acquisition of the role of carer is a specific type of transition of roles in the family, which occurs in response to alterations in health, in the role performed in the relationships, in the expectations or in the competencies, which cause a reduction in self-care in the member of the family who is affected, and who needs increased care on the part of the others. Thus, this construction is defined as a dynamic relationship between the person who carries out the care, the person who needs care, and the community(21).

The fundamental role that nursing has in society translates into perceiving how it is that the human beings deal with processes of transition, and how the surrounding environment affects their coping mechanisms for dealing with these situations. Nursing's contribution is achieved through helping the client (person or family) to maximize their potential or to restore their levels of well-being, health, comfort and self-realization(22-24). This being so, the nurses, who are closest to this context, can identify who the young carers are, what they do, their lifestyle and their needs, both in caring activities and in daily routines. Thus, it is important that the nurses notice the ill person-young carer relationship, as well as their responsibilities ${ }^{(7,10,13,19)}$.

In this way, among health care professionals, it is the nurses who possess the best capacity to identify and enable young carers $^{(2)}$. The nurse can help the dependent family member by providing the members of the family with new knowledge and techniques, noticing how the same are motivated to help the dependent family member and how they adapt to the alterations verified in their expectations, in terms of family roles. It is important to prepare the carers to explore the family dynamic, such that this responsibility may be shared and that each member of the family bears a part of the care $^{(25)}$. The authors also consider that the nurses must intervene in the management and articulation of social support networks, to meet needs that are identified.
The needs of the children as carers have not been analyzed - on the contrary, the needs of the ill family member have been studied more than those of the children. Given that those receiving care mention that the children are better carers than the paid professionals themselves, it becomes even more important to intervene with young carers, to empower them to act in the event of problems in providing care. Once trained, and appropriately informed, they will not underestimate the difficulties they will have in providing care 24 hours a day, such that the levels of stress and caregiver overload will be reduced ${ }^{(9,22)}$.

The operationalization of the interventions related to psychological support is linked to the modeling of the carer's cognitions, through the discovery of new ways of thinking and new coping strategies, such as, for example, support groups, among others(26-27). Nevertheless, the health care professionals themselves must be prepared to work with these children ${ }^{(2,21)}$.

Although the inclusion of the young carers in the discussions about care is one of the aspects to take into account in this context, the health care professionals have not involved the children in their discussions or conversations on the subject ${ }^{(21)}$.

In the light of the literature review undertaken, it was ascertained that the population is becoming older, and that the decision to have children is being taken later, making it predictable that children will increasingly be helping their parents or other close family members, taking on the role of carers. The identification of this reality, and early intervention on the part of nursing professionals, can help these children to feel safer and, therefore, more supported.

\section{Conclusion}

This research allowed the authors to verify that, contrary to the case in, for example, the United Kingdom, Australia, Germany and Canada, there is no production of studies on young carers in Portuguesespeaking countries.

At the same time, from the elaboration of this study, it is possible to assess that this issue has been little developed by the scientific nursing community, which makes it ever more important to study it and deepen knowledge of it, from the perspective of nursing care for young carers and their families. It is crucial for further empirical studies to be undertaken, including in the analysis those already existing in other countries, with the aim of clarifying what the context is, and what the 
role of the nurse should be in this context, particularly in the Portuguese-speaking countries' care context.

\section{References}

1. Warren J. Young carers: Conventional or exaggerated levels of involvement in domestic and caring tasks?. Children Soc. 2007;21:136-46.

2. Becker F, Becker S. Service needs and delivery following the onset of caring amongst children and young adults: Evidenced based review. UK: International Research \& Evaluation; University of Nottingham; 2008.

3. Gays M. Getting it right for young carers in the ACT Family Futures: Issues in research and policy. Canberra (AU): Marymead Child \& Family Centre; 2000.

4. Siskowski C. Young caregivers: Effect of familly health situation on school performance. J School Nurs. 2006;22(3):163-9.

5. Robson E, Ansell N, Huber US, Gould WTS, Young

L. Young caregivers in the context of the HIV/AIDS pandemic in Sub-Saharan Africa. Pop Space Place. 2006;7-22.

6. Becker S. Global perspectives on children's unpaid caregiving in the family research and policy on 'young carers' in the UK, Australia, the USA and Sub-Saharan Africa. Global SOc Policy. 2007;7(1):23-50.

7. Obadina S. Parental Mental IIness: Effects on young carers. Br J School Nurs. 2010;5(3):135-9.

8. Mendes KDS, Silveira RCCP, Galvão CM. Integrative Literature Review: a research method to incorporate evidence in health care and nursing. Rev Texto Contexto. 2008;17(4):758-64.

9. Aldridge J, Becker S. Children who care: Inside the world of young carers. Leicestershire: Loughborough University; 1993. 86 p.

10. Aldridge J, Becker S. My child, my carer: the parent's perspective. Young Carers Res Project. 1994:1-34.

11. Becker S. Young Carers in Europe: An exploratory cross-national study in Britain, France, Sweden and Germany. London (UK): Loughborough University Young Carers Research Group; 1995.

12. Lackey N, Gates M. Adults recollections of their experiences as young caregivers of family members with chronic physical illnesses. J Adv Nurs. 2001;34(3):320-8. 13. Frank J. Making it work: Good practice with young carers and their families. UK: Children's Society and The Princess Royal Trust for Carers; 2002.

14. Banks P, Gallagher E, Hill M, Riddell S. Young carers: Assessments and services Literature review of identification, needs assessment and service provision for young carers and their families. Glasgow: Scottish Executive Central Res Unit; 2002.

15. Thomas N, Stainton T, Jackson S, Cheung WY, Doubtfir S, Webb A. Your friends don't understand Invisibility and unmet need in the lives of young carers. Child Fam Soc Work. 2003 ;8:35-46.

16. Dearden C, Becker S. Young Carers in the UK: the 2004 report. Carers UK. 2004;5-12.

17. Earley L, Cushway D, Cassidy T. Children's perceptions and experiences of care giving: A focus group study. Counsell Psychol Q. March 2007;20(1):69-80.

18. Evans R, Becker S. Hidden Young Carers: The experiences, needs and resilience of children caring for parents and relatives with HIV/AIDS in Tanzania and the UK. Nottingham: University of Nottingham; 2007.

19. Metzing S, Schnepp W, Hübner B, Bücher A. Die Lücke füllen und in Bereitschaft sein: Kinder und Jugendliche als pflegende Angehörige. Pflege \& Gesellschaft. 2007; (11):351-73.

20. Aldridge J. All Work and no Play? Understanding the Needs of Children with Caring Responsibilities. Children Soc. 2008;(22):253-64.

21. Gray B, Robinson C, Seddon D. Invisible Children: Young carers of parents with mental health problems the perspetives of professionals. Child Adolesc Mental Health. 2008;13(4):169-72.

22. Metzing S, Schnepp W. Young carers in Germany: to live on as normal as possible - a grounded theory study. BMC Nursing. 2008;7(15):1-9.

23. Schumacher $K$, Meleis A. Transitions: a central concept in nursing. J Nurs Scholar. 1995;(26):119-27.

24. Meleis A. Theoretical Nursing: Development \& Progress. $4^{a}$ ed. Philadelphia: Lippincott Willians e Wilkins; 2005.

25. Meleis A, Sawyer L, Messias D. H., Schumacher K. Experiencing Transitions: An emerging middle-range theory. Adv Nurs Sci. Sep. 2000;23(1):12-28.

26. Brito LA. Saúde mental dos prestadores de cuidados a familiares idosos. Coimbra: Quarteto Editora; 2002. 27. Zagonel IPS. Transitionary human care in nursing trajectory. Rev. Latino-Am. Enfermagem. 1999;7(3):2532. 
